Sonja Kump

\title{
VPLIV IZOBRAZBE IN SPRETNOSTI STAREJŠIH NA INDIVIDUALNO IN DRUŽBENO BLAGINJO
}

\section{POVZETEK}

Prispevek izhaja iz nekaterih teoretskih razmislekov o starosti in staranju, ki se pojavljajo v razpravah o izobraževanju starejših. Temu sledi predstavitev mednarodnih dokumentov, v katerih je izobraževanje povezano z aktivnim življenjem starejših, ter nekaterih ugotovitev raziskav, ki poudarjajo velik pomen izobraževanja starejših za blaginjo na individualni in družbeni ravni. V nadaljevanju so analizirani podatki raziskave PIAAC o vplivu izobrazbe in spretnosti na področju aktivnega državljanstva, socialne kohezije in osebnega razvoja. Posebej so v ospredju podatki, ki se nanašajo na vzorec starostne skupine 55-65 let v izbranih državah. Ugotovitve analize potrjujejo povezavo med stopnjo izobrazbe in spretnosti starejših odraslih ter individualno in družbeno blaginjo v večini izbranih držav, čeprav je povezanost $v$ nekaterih državah močnejša.

Ključne besede: izobrazba, spretnosti, starejši, prostovoljstvo, zaupanje, zdravje, vpliv na politične procese

\section{THE INFLUENCE OF OLDER ADULTS’ EDUCATION AND SKILLS ON INDI- VIDUAL AND SOCIAL WELL-BEING - ABSTRACT}

This article is based on some theoretical considerations about ageing and old age that are part of the debates on older adults 'education. The paper first focuses on international documents in which education is connected with active ageing and on research results that expose the great significance of older adults' education for well-being on the individual and social levels. Afterwards, it presents the analysis of PIAAC research results about the influence of education and skills on active citizenship, social cohesion, and personal development. The main focus is that of the data relating to the sample age group of 55-65 years old in selected countries. The findings confirm the relationship between education level and skills of older adults with individual and social well-being in most selected countries, although the relationship is stronger in some countries than in others.

Keywords: education, skills, older people, voluntary work, trust, health, influence on political processes

Red.prof.dr. Sonja Kump, Filozofska fakulteta Univerze v Ljubljani, sonja.kump@guest.arnes.si 


\section{IZOBRAŽEVANJE IN STARANJE}

Družbeni problemi, ki izhajajo iz spremenjene starostne strukture prebivalstva, zahtevajo nove rešitve za vzdrževanje prihodnjega družbenega ravnovesja tudi na področju izobraževanja in usposabljanja starejših. Ohranjanje in pridobivanje znanja, kompetenc in spretnosti starejšim ljudem omogoča lažje obvladovanje tveganj, ki jih prinaša življenje v sodobni družbi. Tveganja namreč bolj kot preostale starostne skupine obremenjujejo prav starejše ljudi. Starejši so ena izmed najbolj ranljivih kategorij, saj je ta populacija še posebej izpostavljena različnim tveganjem, kot so poslabšanje finančnega položaja, krčenje socialnih omrežij, zmanjšanje avtonomije in kakovosti življenja. S pomočjo izobraževanja naj bi prišlo do premika v razumevanju od starosti kot »preostanka« nedejavnega, družbeno marginalnega življenja do iskanja pozitivnih potez in pogojev, t. i. dejavnega staranja, razvoja potencialov starejših in njihovega sodelovanja v ekonomskem, kulturnem, političnem in družbenem življenju v skupnosti.

Veliko razprav o izobraževanju in učenju starejših je še vedno prežetih z diskriminatornimi izrazi, ki poudarjajo njihovo šibkost in odvisnost; s tem se zamegljuje dejstvo, da sta učenje in staranje družbeno konstruirana pojma in da lahko imajo pri tem kulturne opredelitve starosti pomembno vlogo v spodbujanju ali omejevanju človekovih aspiracij. Findsen (2005) opozarja na dve prevladujoči teoretični perspektivi v analizi procesa staranja in starosti. Iz funkcionalistične teoretične perspektive so starejši opisani glede na to, kako se prilegajo v obstoječi družbeni red. Primera takšne obravnave sta teorija vlog in teza o nedejavnosti. V teoriji vlog so analizirani družbene vloge starejših, npr. spolne vloge, in vpliv na spreminjanje identitete. Glede na domneve o nedejavnosti so starejši ljudje družbeno segregirani, s tem pa se prekinja njihova fizična in družbena sposobnost. Funkcionalistični pristop zagovarja krčenje področja delovanja $\mathrm{v}$ življenju starejših in temu prilagojeno ponudbo izobraževanja. V funkcionalistični paradigmi je opazna odsotnost obravnave politične, ekonomske in kulturne razsežnosti življenja.

Iz perspektive kritične teorije je staranje družbeni konstrukt in je zato treba nameniti več pozornosti politični ekonomiji, katere del so tudi starejši (Formosa, 2002; 2011). Ta paradigma opozarja na marginalizacijo starejših v mnogih družbah. Zaradi minimalnih prihodkov so finančno prikrajšani; izključeni so iz ponudbe izobraževanja; država in njeni aparati jih uvrščajo v kategorijo »strukturne odvisnosti«. Socialno izključenost in marginalizacijo pogojujejo obstoječe zakonodaje in državne socialne politike, ki starejšim odvzemajo pravico, da bi sodelovali v procesih odločanja, in to celo v primerih, ko se odloča o njihovih potrebah. O njih odločajo mlajše generacije, ki potrebe starejših interpretirajo skozi potrebe svoje generacije.

Za proučevanje kompetenc in spretnosti starejših je pomembna tudi razprava o konceptih starosti, ki razlikuje med dvema perspektivama; ti dve si v zgodovinskem razvoju ne sledita nujno prva drugi (Manheimer, Snodgrass in Moskow-McKenzie, 1995, str. 35). »Tradicionalna perspektiva osebnega prilagajanja « predpostavlja, da starejša oseba nima izbire, ampak se lahko zgolj prilagaja novim okoliščinam in jih ustrezno obvladuje. »Moderna 
perspektiva osebne transformacije « zavrača starosti primerne vloge, ki so opredeljene s kulturnimi vzorci in klasičnimi vrlinami starosti kot oblikami družbenega stereotipiziranja. V tej perspektivi je poznejše življenje nepopisana zgodovina, ki jo ustvari vsaka oseba zase, pri tem pa je omejena le z lastno imaginacijo in pritiski družbe po prilagajanju. Zaradi različnosti biološkega staranja ter individualnosti posameznikovega doživljanja življenja in okolja si starejši ljudje nikakor niso podobni in ne sestavljajo uniformne družbene skupine. Iz različnih razprav lahko torej sklepamo, da kronološka leta niso najbolj relevantni dejavnik v razumevanju obdobja.

\section{MEDNARODNI DOKUMENTI O IZOBRAŽEVANJU STAREJŠIH}

Generalna skupščina Združenih narodov je leta 1991 sprejela načela za starejše osebe, ki so bila ponovno razglašena v mednarodnem letu starejših v letu 1999 (United Nations, 1991). Pomen izobraževanja in učenja starejših je vključen $v$ treh načelih. V povezavi $\mathrm{z}$ načelom neodvisnosti je treba starejšim omogočiti dostop do ustreznih programov izobraževanja in usposabljanja. Načelo participacije opozarja na pomen integracije starejših $\mathrm{v}$ družbo, na njihovo aktivno sodelovanje pri oblikovanju in implementaciji politik, ki neposredno vplivajo na njihovo blaginjo, ter na pomen prenosa znanja in spretnosti starejših na mlajše generacije. $\mathrm{V}$ načelu samoizpolnitve je poudarjeno omogočanje priložnosti za popoln razvoj potencialov starejših, s tem da imajo dostop do izobraževalnih, kulturnih, duhovnih in rekreacijskih virov družbe. Tudi na drugi svetovni skupščini Združenih narodov o staranju je bilo izobraževanje poudarjeno kot glavni temelj za aktivno in izpolnjeno življenje. Deklaracija, sprejeta na skupščini, vključuje opozorilo, da je starejšim treba zagotoviti priložnosti, programe in podporo, da sodelujejo oz. nadaljujejo sodelovanje $\mathrm{v}$ kulturnem, ekonomskem, političnem in socialnem življenju ter vseživljenjskem učenju (United Nations, 2002). V okviru iste svetovne skupščine je politični okvir za aktivno staranje predstavila Svetovna zdravstvena organizacija (WHO, 2002). V njenem dokumentu sta izobraževanje in vseživljenjsko učenje obravnavana kot pomembna dejavnika za zagotavljanje zdravja, participacijo in varnost v kasnejšem življenju. Za dosego teh ciljev pa je pomembno sprejetje do starosti prijaznih politik.

Da zavedanje o pomenu izobraževanja in učenja starejših odraslih narašča, pričajo tudi številni dokumenti Evropske komisije, ki se sklicujejo na vseživljenjsko učenje (European Commission, 2000; European Commission, 2001) in ga med drugim povezujejo s problemi staranja prebivalstva, krčenjem števila rojstev in strukturno brezposelnostjo (European Commission, 2006; European Commission, 2007). V te politične smernice so vključeni predlogi implementacije izobraževalnih možnosti za starejše odrasle, velik poudarek je na zagotavljanju učnih priložnosti za starejše delavce, ki naj bi zagotavljale daljšanje aktivnega delovnega življenja posameznikov. Tudi Resolucija Sveta Evropske unije o prenovljenem evropskem programu za izobraževanje odraslih, ki naj bi ga države članice izvajale do leta 2020, opozarja na pomen dobro razvitega izobraževanja starejših, s katerim bi spodbujali aktivno, samostojno in zdravo staranje ter uporabili njihovo znanje, spretnosti, izkušnje ter socialni in kulturni kapital v korist družbe kot celote (Svet Evropske unije, 2011). V tem 
evropskem programu je med prednostna področja za obdobje 2012-2014 uvrščeno spodbujanje pravičnosti, socialne kohezije in aktivnega državljanstva s pomočjo izobraževanja odraslih in v tej zvezi izboljšanje učnih možnosti za starejše v okviru aktivnega staranja, vključno s prostovoljstvom in spodbujanjem inovativnih oblik medgeneracijskega učenja.

\section{POMEN IN VLOGA IZOBRAŽEVANIA STAREJŠIH}

Strokovne razprave o vlogi izobraževanja starejših in problemih staranja so se začele pojavljati pred približno 30 leti, in sicer v okvirih tako imenovane izobraževalne gerontologije (Allman, 1984; Battersby, 1987; Glendenning, 1992; Formosa, 2002). V tistih časih večina političnih načrtovalcev izobraževanja še ni razmišljala o možnostih izobraževanja in učenja starejših. Toda postopoma, zlasti s spremembami v starostni strukturi prebivalstva, spremenjenimi vzorci zaposlovanja in pomembnim izboljšanjem zdravstvene oskrbe starejših, se je krepilo prepričanje o pomenu in vlogi tega področja izobraževanja (Klercq, 2004; Withnall, 2006).

Pomen izobraževanja starejših potrjujejo ugotovitve antropoloških, andragoških, socioloških in medicinskih raziskav, saj poudarjajo pozitivni vpliv izobraževanja v starosti na zdravje, socialno dejavnost starejše osebe in njene možnosti pridobivanja ter ohranjanja moči in vpliva (Glendenning, 2000; Jarvis, 2001; Withnall, 2010; Findsen in Formosa, 2011). Izobraževanje, ki lahko vpliva na razvoj potencialov starejših in njihovo sodelovanje v ekonomskem, kulturnem, političnem in družbenem življenju, ima za starejšega človeka več funkcij: ohranjanje mentalnih/kognitivnih sposobnosti, zadovoljevanje socialnih potreb, osebni razvoj, ohranjanje fizične dejavnosti, razumevanje družbenih sprememb, povečevanje zadovoljstva in harmonije (Illeris, 2004; Bjorklund in Bee, 2008). Hkrati pa je izobraževanje tudi element blaginje lokalne skupnosti, saj se z izobraževalnimi dejavnostmi poleg učenja spodbujajo druženje, sodelovanje, izmenjava znanja, spretnosti, izkušenj in informacij med starejšimi samimi ter tudi s pripadniki mlajših generacij, ohranja se solidarnost (Cappeliez, Beaupre, Robitaille, 2008).

Raziskave kažejo, da obstajajo povezave med stopnjo izobrazbe in mnogimi vidiki individualne in družbene blaginje; bolj izobraženi ljudje živijo dlje, v bolj zdravem okolju, prenašajo več življenjskega/fizičnega in kulturnega kapitala na svoje otroke ipd. (Schuller, 2004, str. 4). Nasprotno pa slabše izobraženi starejši pogosteje živijo pod pragom revščine, se ne znajdejo dobro pri iskanju možnosti zdravstvene in socialne pomoči, si ne morejo privoščiti zdrave prehrane in drugih ugodnosti, pogosteje zbolijo in prej umirajo. Manj izobraženi starejši pa se tudi redkeje odločajo za izobraževanje v okviru ponujenih možnosti, namenjenih predvsem starejšim.

V zadnjih desetletjih se na izobraževanje vse bolj gleda tudi kot na potrebo starejših ljudi. $\mathrm{Z}$ izobraževanjem se vzpostavljajo možnosti in podlage za t. i. uspešno staranje ali tudi dejavno staranje; izobraževanje vpliva na izrabo in razvoj potencialov starejših (npr. samouresničevanje, osebnostna rast) in na krepitev njihove družbene moči, s tem pa tudi na zmanjševanje njihove marginalizacije, ki nastaja pod vplivom ekonomskih, socialnih, 
političnih in kulturnih dejavnikov. Skratka, z izobraževanjem starejših se utrjujeta njihov družbeni položaj in integracija v družbo, spodbuja se delovanje starejših v skupnosti, povezovanje mladih in starih ter ustvarjanje družbe vseh starosti.

\section{VPLIV SPRETNOSTI IN IZOBRAZBE STAREJŠIH NA NEEKONOMSKEM PODROČJu}

Raziskava OECD »Survey of Adult Skills« (PIAAC) je pretežno osredotočena na vpliv spretnosti posameznikov, ki se kaže na ekonomskem področju, kot je npr. vpliv spretnosti na zaslužek in ekonomsko rast. Manjšina pozornosti pa je namenjena vplivu izobrazbe in spretnosti na področju aktivnega državljanstva, socialne kohezije in osebnega razvoja. V raziskavi PIAAC so vprašanja o sodelovanju v prostovoljski dejavnosti, ravni zaupanja, vplivu na politične procese in o samooceni zdravja opredeljena kot štiri dimenzije družbene in osebne blaginje, razumljene v širšem smislu (OECD 2013, str. 234).

Na splošno je v vseh 23 državah, ki so v letih 2011 in 2012 sodelovale v raziskavi PIA$\mathrm{AC}$, velika verjetnost, da bodo posamezniki z nizko ravnijo spretnosti pismenosti in nižjo stopnjo dosežene izobrazbe bolj pogosto kot tisti z višjimi ravnmi spretnosti pismenosti in višjimi stopnjami izobrazbe poročali o slabem zdravju, bili prepričani o tem, da imajo majhen vpliv na politične procese, ter redkeje sodelovali $\mathrm{v}$ društvenih in prostovoljskih dejavnostih, prav tako pa bolj pogosto ne zaupajo drugim. Čeprav so vzorci v odgovorih podobni v večini držav, je povezanost med ravnmi spretnosti in kazalniki blaginje $\mathrm{v}$ nekaterih državah večja kot $\mathrm{v}$ drugih. Za podrobnejše razlage razlik med državami bi bile potrebne poglobljene analize socialnih, kulturnih, zgodovinskih in političnih okoliščin v posameznih državah.

\section{Sodelovanje v prostovoljski dejavnosti}

Ena od dimenzij blaginje v raziskavi PIAAC je prostovoljstvo. Koristi prostovoljstva za posameznike so raznolike, saj si prostovoljec s prostovoljskim delom lahko pridobi nova znanja in izkušnje, razvije nove socialne spretnosti, si razširi socialno mrežo, poveča samozaupanje itd. (Gabrijelčič Blenkuš in Scagnetti, 2014). S prostovoljskim delom se v družbi krepita povezanost med ljudmi in solidarnost, spodbuja se aktivno državljanstvo. Rezultati raziskave na celotnem vzorcu anketiranih v izbranih državah kažejo, da odrasli z višjimi ravnmi spretnosti in višjo ali visoko stopnjo izobrazbe bolj pogosto sodelujejo v prostovoljskih dejavnostih kot tisti z nižjimi ravnmi spretnosti in nižjimi stopnjami dosežene izobrazbe. 
Tabela 1: Udeležba v prostovoljskih dejavnostih

\begin{tabular}{|l|l|l|l|l|l|l|}
\hline $\begin{array}{l}\text { IZBRANE } \\
\text { DRŽAVE }\end{array}$ & $\begin{array}{l}\text { Raven 2 } \\
\text { ali manj; } \\
\text { manj kot } \\
\text { srednja } \\
\text { šola }\end{array}$ & $\begin{array}{l}\text { Raven 2 } \\
\text { ali manj; } \\
\text { srednja } \\
\text { šola }\end{array}$ & $\begin{array}{l}\text { Raven 2 } \\
\text { ali mani; } \\
\text { višja/visoka } \\
\text { šola }\end{array}$ & $\begin{array}{l}\text { Raven 3 } \\
\text { ali več; } \\
\text { manj kot } \\
\text { srednja } \\
\text { šla }\end{array}$ & $\begin{array}{l}\text { Raven 3 } \\
\text { ali več; } \\
\text { srednja } \\
\text { šola }\end{array}$ & $\begin{array}{l}\text { Raven 3 } \\
\text { ali več; } \\
\text { višja/visoka } \\
\text { šola }\end{array}$ \\
\hline Belgija & 0,5425 & 0,6343 & 0,7486 & 0,6851 & 0,7324 & 0,8055 \\
\hline Češka & 0,5472 & 0,6023 & 0,6244 & 0,6982 & 0,6817 & 0,7554 \\
\hline Estonija & 0,5582 & 0,6925 & 0,7851 & 0,6928 & 0,7356 & 0,8299 \\
\hline Finska & 0,5542 & 0,6146 & 0,7090 & 0,6785 & 0,6981 & 0,7530 \\
\hline Irska & 0,5144 & 0,6386 & 0,7103 & 0,6191 & 0,6812 & 0,7640 \\
\hline Italija & 0,4747 & 0,5505 & 0,6393 & 0,5033 & 0,6515 & 0,6956 \\
\hline Norveška & 0,5368 & 0,6370 & 0,6962 & 0,6995 & 0,7097 & 0,7290 \\
\hline Poljska & 0,4418 & 0,4589 & 0,6973 & 0,6469 & 0,5019 & 0,7352 \\
\hline Španija & 0,5052 & 0,6978 & 0,7465 & 0,5989 & 0,7288 & 0,7786 \\
\hline Švedska & 0,5552 & 0,5954 & 0,6869 & 0,5965 & 0,7077 & 0,7296 \\
\hline Z. kraljestvo & 0,4878 & 0,6695 & 0,7390 & 0,7000 & 0,7743 & 0,8423 \\
\hline
\end{tabular}

Vir: podatki za izbrane države so povzeti iz »OECD Skills Outlook 2013« (OECD, 2013, str. 405), Table A6.14, Part $3 / 4$.

Povprečno je verjetnost, da posamezniki, ki dosegajo 4. ali 5. raven spretnosti pismenosti, sodelujejo v prostovoljski dejavnosti, dvakrat večja v primerjavi s posamezniki, ki dosegajo 1. raven spretnosti ali manj (OECD, 2013, str. 239). V Tabeli 1 je predstavljena povezava udeležbe v prostovoljskih dejavnostih $\mathrm{z}$ doseganjem 2. in 3. ravni spretnosti pismenosti ter stopnjo izobrazbe. Med tistimi, ki dosegajo 2. ali 3. raven spretnosti pismenosti, so v večini izbranih držav opazne razlike med različnimi stopnjami izobrazbe. Udeležba v prostovoljski dejavnosti v okviru iste ravni spretnosti premosorazmerno narašča z zviševanjem stopnje dosežene izobrazbe. Izjema je Češka, kjer so tisti s srednješolsko izobrazbo ali manj in ki hkrati dosegajo 3. raven spretnosti pismenosti, opazno bolj aktivni v prostovoljstvu kot tisti, ki imajo višjo ali visokošolsko izobrazbo in dosegajo 2 . stopnjo spretnosti pismenosti.

Prostovoljstvo je povezano $\mathrm{z}$ blaginjo starejših in blaginjo družbe, saj lahko prispeva $\mathrm{k}$ zmanjševanju javnih izdatkov. Starejšim prostovoljstvo pomeni možnost, da še naprej ostanejo aktivni v družbi. Ker so prostovoljci vključeni v več družbenih omrežij, so manj osamljeni, hkrati pa pridobijo več moči, podpore in znanja (vključno z znanjem o zdravju). Ko pomagajo drugim, se krepi njihovo samospoštovanje, saj se počutijo bolj potrebne in spoštovane. Tako jih lahko prostovoljstvo ščiti pred depresijo in nizko samopodobo, ki sta v kasnejših letih pogosti. Za nekatere ima prostovoljsko delo pomembno vlogo ob prehodu v upokojitev, ko se morajo prilagoditi spremenjenim okoliščinam, ki jih silijo, da si v novi situaciji na novo uredijo svoje življenje (Pavelek, 2012). Kahana, Bhatta, Lovegreen, 
Kahana in Midlarsky (2013) so v obsežni raziskavi ugotovili, da kombinacija altruističnih vrednot, prostovoljstva in nudenja neformalne pomoči pripomore k zadovoljstvu z življenjem in ima še druge pozitivne učinke na blaginjo starejših. Tudi longitudinalne raziskave kažejo na neposredno povezanost med prostovoljstvom in blaginjo (Haski-Leventhal, 2009, str. 391). Starejši prostovoljci so bolj fizično in psihično zdravi (Anderson idr., 2014), kar je lahko učinek prostovoljskega dela, lahko pa to pomeni tudi, da so prostovoljci sicer bolj zdravi in se zato laže vključujejo v prostovoljstvo. Raziskave o prostovoljstvu starejših opozarjajo na nekatere ovire, ki starejše odvračajo od te vrste dejavnosti. Te ovire so pogosto povezane z zdravjem, mobilnostjo in financami. Veliko praktičnih ovir je povezanih s komunikacijo; potrebno je ustrezno informiranje o možnostih prostovoljskega dela (oglasne deske, bilteni ...).

Naša analiza je vključevala mednarodno bazo PIAAC (Survey of Adults Skills, 2012), ki vsebuje podatke okoli 166.000 odraslih iz 24 držav, ki so sodelovale v prvem krogu raziskave. Podatke o sodelovanju v prostovoljskih dejavnostih v izbranih državah za starostno skupino 55-65 let smo najprej križali z njihovim delovnim statusom. Preverjali smo hipotezo, da so zaposleni starejši bolj pogosto vključeni v prostovoljsko dejavnost kot starejši, ki so upokojeni ali brezposelni.

Tabela 2: Starejši (55-65 let) po delovnem statusu in neudeležbi v prostovoljskem delu

\begin{tabular}{|c|c|c|c|c|c|c|}
\hline IZBRANE DRŽAVE & \multicolumn{2}{|c|}{$\begin{array}{l}\text { Zaposleni ali } \\
\text { samozaposleni }\end{array}$} & \multicolumn{2}{|c|}{ Upokojeni } & \multicolumn{2}{|c|}{$\begin{array}{l}\text { Brezposelni, ki } \\
\text { iščejo delo }\end{array}$} \\
\hline Belgija & 259 & 66,70 & 266 & 64,93 & 40 & 69,84 \\
\hline Češka & 423 & 83,76 & 632 & 89,83 & 50 & 99,36 \\
\hline Estonija & 679 & 74,38 & 421 & 86,46 & 77 & 77,12 \\
\hline Finska & 416 & 54,48 & 260 & 59,90 & 64 & 68,38 \\
\hline Francija & 529 & 74,48 & 488 & 71,83 & 65 & 78,25 \\
\hline Irska & 266 & 55,05 & 146 & 62,46 & 57 & 65,56 \\
\hline Italija & 271 & 74,46 & 280 & 77,97 & 45 & 89,92 \\
\hline Norveška & 281 & 44,66 & 48 & 54,86 & 6 & 54,20 \\
\hline Poljska & 253 & 78,61 & 424 & 87,33 & 62 & 92,73 \\
\hline Španija & 315 & 79,27 & 195 & 81,00 & 111 & 88,51 \\
\hline Švedska & 428 & 61,83 & 160 & 67,94 & 30 & 73,03 \\
\hline Združeno kraljestvo & 574 & 69,68 & 364 & 59,82 & 63 & 76,84 \\
\hline
\end{tabular}

Vir: mednarodna baza PIAAC (Survey of Adults Skills, 2012). 
Križanje podatkov hipotezo v glavnem potrjuje v večini držav, razen v Belgiji, Franciji in Združenem kraljestvu, kjer je med neaktivnimi nekoliko manj upokojencev kot zaposlenih in samozaposlenih (Tabela 2). V vseh državah je najmanj vključenih v prostovoljsko dejavnost med starejšimi brezposelnimi, pri tem še zlasti izstopajo Češka, Poljska, Italija in Španija. Primerjava med državami pokaže, da so v vseh treh kategorijah starejši na področju prostovoljstva najbolj aktivni na Norveškem, Irskem in Finskem, najmanj pa na Češkem in Poljskem.

Čeprav so spretnosti procesiranja informacij rezultat učenja v različnih kontekstih skozi vse življenje, rezultati prejšnjih raziskav OECD (OECD, 2013, str. 242) kažejo, da zlasti izobrazba pomembno vpliva na oblikovanje ključnih spretnosti procesiranja informacij. Obseg povezanosti med izobrazbo in različnimi družbenimi učinki se izraža ravno skozi ključne spretnosti procesiranja informacij in zato OECD predlaga, naj izobraževalni sistemi temu področju namenijo še več pozornosti. Raziskave kažejo, da ima izobrazba pozitivni vpliv na socialno kohezijo in aktivno državljanstvo. Feinstein, Budge, Vorhausin in Duckworth (2008) so ugotovili pozitivno povezavo med izobrazbo in večjim zaupanjem, pogostejšim sodelovanjem v civilni družbi in nižjimi stopnjami kriminala v družbi. Prav tako so ugotovili, da posameznikova vključenost v izobraževanje napoveduje njegovo sodelovanje in pozitivno vlogo $\mathrm{v}$ javnem življenju.

Ker ima v večini držav izobrazba zelo pomemben vpliv na področje socialne in politične participacije, včasih bolj kot raven spretnosti, smo v analizi vzorca starejših v izbranih državah dali prednost stopnji njihove formalne izobrazbe.

Tabela 3: Starejši (55-65 let) po stopnii izobrazbe in neudeležbi v prostovoljskem delu

\begin{tabular}{|c|c|c|c|c|c|c|}
\hline IZBRANE DRŽAVE & \multicolumn{2}{|c|}{$\begin{array}{l}\text { Manj kot srednješolska } \\
\text { izobrazba }\end{array}$} & \multicolumn{2}{|c|}{$\begin{array}{l}\text { Srednješolska } \\
\text { izobrazba }\end{array}$} & \multicolumn{2}{|c|}{$\begin{array}{l}\text { Višja in visokošolska } \\
\text { izobrazba }\end{array}$} \\
\hline Belgija & 253 & 74,92 & 269 & 67,47 & 162 & 55,61 \\
\hline Češka & 113 & 93,76 & 839 & 88,24 & 241 & 81,91 \\
\hline Estonija & 208 & 88,45 & 630 & 83,83 & 528 & 73,21 \\
\hline Finska & 240 & 67,10 & 290 & 59,93 & 279 & 48,50 \\
\hline Francija & 560 & 81,42 & 481 & 74,55 & 192 & 58,10 \\
\hline Irska & 337 & 71,73 & 105 & 54,40 & 198 & 43,23 \\
\hline Italija & 429 & 80,93 & 223 & 66,59 & 107 & 74,63 \\
\hline Norveška & 81 & 61,82 & 153 & 51,08 & 218 & 45,61 \\
\hline Poljska & 178 & 93,79 & 582 & 87,63 & 159 & 72,30 \\
\hline Španija & 621 & 87,35 & 118 & 74,91 & 133 & 68,03 \\
\hline Švedska & 133 & 73,04 & 273 & 66,17 & 232 & 65,17 \\
\hline Združeno kraljestvo & 447 & 83,21 & 463 & 71,29 & 307 & 50,56 \\
\hline
\end{tabular}

Vir: mednarodna baza PIAAC (Survey of Adults Skills, 2012). 
Domnevali smo, da starejši z doseženo višjo ali visoko stopnjo izobrazbe bolj pogosto prostovoljsko delujejo kot starejši z nižjimi stopnjami izobrazbe. Tudi tokrat je križanje podatkov potrdilo našo domnevo, saj neaktivnost v prostovoljski dejavnosti premosorazmerno upada $\mathrm{z}$ višjo stopnjo dosežene izobrazbe (Tabela 3). Izjema je Italija, kjer so starejši s srednješolsko izobrazbo bolj aktivni v prostovoljstvu kot tisti, ki imajo višjo ali visokošolsko izobrazbo. V vseh treh kategorijah je največ neaktivnih v nekdanjih socialističnih državah, tj. na Češkem, Poljskem in v Estoniji. Na splošno je med starejšimi prostovoljci več tistih, ki so bolj izobraženi ter sorazmerno dobro finančno in socialno situirani. V primerjavi s temi relativno privilegiranimi se mnogi starejši ukvarjajo predvsem z vprašanjem, kako preživeti. Med tema skupinama starejših tudi glede želje in pripravljenosti za izobraževanje obstaja veliko razhajanje.

\section{Zaupanje v druge ljudi}

$\mathrm{V}$ raziskavi PIAAC je drugi kazalnik blaginje stopnja zaupanja, ki je podlaga demokracije. Po mnenju Sztompke (1999) so brez zaupanja v druge vsi odnosi, naj bodo poslovni, politični ali socialni, manj učinkoviti. Temelji zaupanja se vzpostavljajo na treh komplementarnih ravneh; zaupanje kot individualna poteza, zaupanje kot odnos in zaupanje kot kulturno pravilo. Določene spretnosti posameznika lahko vodijo do zaupanja v druge. Ključne spretnosti za procesiranje informacij na primer lahko ljudem omogočajo boljše razumevanje motivov in aspiracij drugih ljudi in pogojev, v katerih se to izraža. Spretnosti lahko tudi omogočajo, da ljudje vzpostavijo zaupanje z negovanjem trajnih odnosov, katerih cilj je doseganje vzajemnih rezultatov (OECD, 2013, str. 237).

Rezultati PIAAC na celotnem vzorcu anketiranih v izbranih državah (OECD, 2013, str 238) kažejo, da ljudje z nižjimi spretnostmi pismenosti manj zaupajo drugim; tako na primer posamezniki, ki dosegajo 1. raven spretnosti pismenosti, drugim ne zaupajo dvakrat bolj pogosto kot posamezniki, ki dosegajo 4. ali 5. raven spretnosti pismenosti. Torej rezultati PIAAC izkazujejo jasno povezanost med zaupanjem in pismenostjo. Zaupanje je lepilo sodobnih družb in brez zaupanja so lahko ljudje bolj izpostavljeni tveganju. Zaupanje kot temeljna državljanska spretnost se izraža v vrednotenju politike kot inkluzivne, ki se gradi in implementira s pomočjo dejanskega angažmaja državljanov (Motschilnig, 2014). 
Tabela 4: Visoke ravni zaupanja

\begin{tabular}{|l|l|l|l|l|l|l|}
\hline $\begin{array}{l}\text { IZBRANE } \\
\text { DRŽAVE }\end{array}$ & $\begin{array}{l}\text { Raven 2 } \\
\text { ali manj; } \\
\text { manj kot } \\
\text { srednja } \\
\text { šola }\end{array}$ & $\begin{array}{l}\text { Raven 2 } \\
\text { ali manj; } \\
\text { srednja } \\
\text { šola }\end{array}$ & $\begin{array}{l}\text { Raven 2 } \\
\text { ali manj; } \\
\text { višja/visoka } \\
\text { šola }\end{array}$ & $\begin{array}{l}\text { Raven 3 } \\
\text { ali več; } \\
\text { manj kot } \\
\text { srednja } \\
\text { šola }\end{array}$ & $\begin{array}{l}\text { Raven 3 } \\
\text { ali več; } \\
\text { srednja } \\
\text { šola }\end{array}$ & $\begin{array}{l}\text { Raven 3 } \\
\text { ali več; } \\
\text { višja/visoka } \\
\text { šola }\end{array}$ \\
\hline Belgija & 0,5242 & 0,6000 & 0,7678 & 0,5203 & 0,6568 & 0,8255 \\
\hline Češka & 0,5421 & 0,5058 & 0,5874 & 0,6194 & 0,5117 & 0,8011 \\
\hline Estonija & 0,4530 & 0,3924 & 0,5462 & 0,4556 & 0,4059 & 0,6309 \\
\hline Finska & 0,5078 & 0,5873 & 0,7234 & 0,5398 & 0,6056 & 0,7660 \\
\hline Irska & 0,5141 & 0,5710 & 0,6585 & 0,5910 & 0,6193 & 0,7496 \\
\hline Italija & 0,5400 & 0,7017 & 0,7304 & 0,6426 & 0,7605 & 0,8341 \\
\hline Norveška & 0,4861 & 0,5145 & 0,6835 & 0,5687 & 0,6299 & 0,7915 \\
\hline Poljska & 0,4709 & 0,4943 & 0,6494 & 0,5972 & 0,5672 & 0,7295 \\
\hline Španija & 0,4792 & 0,5553 & 0,6524 & 0,5453 & 0,6050 & 0,7212 \\
\hline Švedska & 0,4620 & 0,5178 & 0,6642 & 0,5688 & 0,6205 & 0,7695 \\
\hline Z. kraljestvo & 0,4600 & 0,5432 & 0,6830 & 0,5022 & 0,6766 & 0,7732 \\
\hline
\end{tabular}

Vir: podatki za izbrane države so povzeti iz »OECD Skills Outlook 2013 « (OECD, 2013, str. 404), Table A6.14, Part $1 / 4$.

V Tabeli 4 je razvidna splošna povezanost med stopnjo izobrazbe, ravnijo spretnosti pismenosti in zaupanjem v druge ljudi, čeprav so pomembne tudi razlike med državami. Zanimiva se zdi razlika med vplivom ravni spretnosti in vplivom izobrazbe na stopnjo zaupanja. Tako ima v večini držav izobrazba večji vpliv na raven zaupanja kot raven spretnosti. To se kaže predvsem v primerjavi vpliva višje in visoke stopnje izobrazbe tistih, ki dosegajo drugo raven spretnosti, in tistih, ki imajo manj kot srednješolsko izobrazbo in dosegajo tretjo raven spretnosti pismenosti. Izjema je le Češka, kjer je povezava s stopnjo zaupanja večja pri tistih, ki dosegajo tretjo raven pismenosti in imajo manj kot srednješolsko izobrazbo, kot pri posameznikih, ki imajo višjo in visoko stopnjo izobrazbe in dosegajo drugo raven spretnosti.

Na vzorcu starejših (55-65 let) smo v naši analizi preverjali domnevo, da starejši, ki v zadnjih 12 mesecih niso opravljali prostovoljskega dela, bolj pogosto menijo, da je mogoče zaupati samo peščici ljudi, kot starejši, ki delujejo kot prostovoljci. Putnam (2000) je zaupanje in sodelovanje $\mathrm{v}$ prostovoljskih dejavnostih povezoval s pojmom socialnega kapitala, ki pomeni skupek sodelovanja, norm, socialnih mrež, vzajemnosti, zaupanja, prostovoljstva in dejavnosti v skupnosti (Putnam, 2000). Kot ugotavlja Field (2005), se pomembnost socialnega kapitala kaže $\mathrm{v}$ povezovanju ljudi in njihovem prizadevanju za boljše življenje, hkrati pa ima pomembno vlogo pri demokratizaciji družbe. 
Tabela 5: Starejši (55-65 let), ki se ne udeležujejo prostovoliske dejavnosti, in stopnja njihovega zaupanja $\checkmark$ druge liudi

\begin{tabular}{|c|c|c|c|c|}
\hline \multirow[t]{2}{*}{ IZBRANE DRŽAVE } & \multicolumn{2}{|c|}{$\begin{array}{l}\text { Zaupati je mogoče samo peščici } \\
\text { ljudi: Zelo se strinjam } \\
\text { Strinjam se }\end{array}$} & \multicolumn{2}{|c|}{$\begin{array}{l}\text { Zaupati je mogoče samo peščic } \\
\text { liudi: Ne strinjam se } \\
\text { Sploh se ne strinjam }\end{array}$} \\
\hline & Število & $\%$ odgovorov & Število & $\%$ odgovorov \\
\hline Belgija & 514 & 74,59 & 107 & 15,85 \\
\hline Češka & 1.054 & 97,67 & 71 & 4,89 \\
\hline Estonija & 1.184 & 85,96 & 99 & 7,52 \\
\hline Finska & 539 & 67,73 & 208 & 24,76 \\
\hline Francija & 1.020 & 83,63 & 93 & 7,52 \\
\hline Irska & 522 & 81,36 & 84 & 13,50 \\
\hline Italija & 619 & 84,89 & 76 & 8,84 \\
\hline Norveška & 276 & 61,60 & 144 & 30,06 \\
\hline Poljska & 744 & 80,31 & 90 & 10,62 \\
\hline Španija & 623 & 71,79 & 147 & 16.36 \\
\hline Švedska & 355 & 56,30 & 235 & 35,66 \\
\hline Združeno kraljestvo & 953 & 76,93 & 182 & 15,31 \\
\hline
\end{tabular}

Vir: mednarodna baza PIAAC (Survey of Adults Skills, 2012).

$S$ križanjem podatkov je naša hipoteza v glavnem potrjena, čeprav so med državami pomembne razlike (Tabela 5). Povezava je zlasti močna na Češkem, v Estoniji in Italiji, veliko manj pa v treh nordijskih državah. Razlike med skupinami držav lahko pojasnimo $\mathrm{z}$ ugotovitvami raziskave o tem, ali imajo prostovoljci večje zaupanje $\mathrm{v}$ druge $\mathrm{v}$ primerjavi z neprostovoljci, ki je bila izvedena na Norveškem in Češkem. Primerjalna analiza je pokazala, da je $\mathrm{v}$ državah $\mathrm{z}$ močnim sistemom blaginje (univerzalna država blaginje) in nizkim zaznavanjem korupcije, kot je denimo Norveška, zaznati tudi visoko raven zaupanja (Sivesind, Posṕišilová, Frič, 2013, str. 124). V teh državah ima prostovoljstvo močne pozitivne učinke na generalizirano zaupanje. V državah, kjer je sistem družbene blaginje šibkejši in zaznavanje korupcije večje (primer Češke), imajo hkrati tudi nižje ravni zaupanja. $\mathrm{V}$ teh državah prostovoljstvo ne vpliva na povečano zaupanje v institucije, hkrati pa ima močen pozitivni učinek na generalizirano družbeno zaupanje (prav tam, str. 125).

\section{Aktivno državljanstvo}

Tretja dimenzija blaginje oz. kazalnik aktivnega državljanstva v raziskavi PIAAC (OECD, 2013, str. 240) se nanaša na prepričanje posameznikov, da imajo vpliv na delovanje vlade, skratka, da verjamejo v svojo moč vplivanja na spremembe. Rezultati kažejo, da so za razumevanje političnih problemov pomembne spretnosti pismenosti in izobrazba. Za boljše razumevanje političnih problemov v državi ljudje potrebujejo informacije, ki jih 
lahko pridobijo v časopisih, knjigah, revijah in na spletu. Pri tem pa so pomembne višje ravni spretnosti ocenjevanja, interpretiranja in analiziranja informacij. Še zlasti potrebne so spretnosti kritičnega branja informacij o aktualnih političnih zadevah, na splošno pa tudi spretnosti za procesiranje informacij, ki omogočajo širši domet učnih izkušenj, s pomočjo katerih lahko posamezniki razvijejo boljše razumevanje kompleksnosti družbe.

Tabela 6: Visoke ravni vpliva na politične procese

\begin{tabular}{|l|l|l|l|l|l|l|}
\hline $\begin{array}{l}\text { IZBRANE DR- } \\
\text { ŽAVE }\end{array}$ & $\begin{array}{l}\text { Raven 2 } \\
\text { ali mani; } \\
\text { manj kot } \\
\text { srednja } \\
\text { šola }\end{array}$ & $\begin{array}{l}\text { Raven 2 } \\
\text { ali mani; } \\
\text { srednja } \\
\text { šola }\end{array}$ & $\begin{array}{l}\text { Raven 2 } \\
\text { ali mani; } \\
\text { višja/visoka } \\
\text { šola }\end{array}$ & $\begin{array}{l}\text { Raven 3 } \\
\text { ali več; } \\
\text { manj kot } \\
\text { srednja } \\
\text { šola }\end{array}$ & $\begin{array}{l}\text { Raven 3 } \\
\text { ali več; } \\
\text { srednja } \\
\text { šola }\end{array}$ & $\begin{array}{l}\text { Raven 3 } \\
\text { ali več; } \\
\text { višja/visoka } \\
\text { šola }\end{array}$ \\
\hline Belgija & 0,5371 & 0,5973 & 0,6974 & 0,6138 & 0,6719 & 0,7896 \\
\hline Češka & 0,5575 & 0,5082 & 0,6504 & 0,5237 & 0,5909 & 0,6624 \\
\hline Estonija & 0,5256 & 0,5644 & 0,6498 & 0,6028 & 0,7089 & 0,7756 \\
\hline Finska & 0,4939 & 0,6027 & 0,7184 & 0,5731 & 0,6825 & 0,7910 \\
\hline Irska & 0,4894 & 0,6076 & 0,7399 & 0,5355 & 0,6812 & 0,7704 \\
\hline Italija & 0,5089 & 0,6442 & 0,7739 & 0,6695 & 0,6958 & 0,7706 \\
\hline Norveška & 0,4677 & 0,5771 & 0,6951 & 0,6381 & 0,6895 & 0,8268 \\
\hline Poljska & 0,4999 & 0,5803 & 0,6993 & 0,5903 & 0,6412 & 0,7836 \\
\hline Španija & 0,5028 & 0,5541 & 0,6322 & 0,5461 & 0,6228 & 0,6714 \\
\hline Švedska & 0,4354 & 0,4520 & 0,5849 & 0,5443 & 0,6074 & 0,6892 \\
\hline Z. kraljestvo & 0,4847 & 0,5813 & 0,6557 & 0,6351 & 0,6778 & 0,7732 \\
\hline
\end{tabular}

Vir: podatki za izbrane države so povzeti iz »OECD Skills Outlook 2013« (OECD, 2013, str. 404), Table A6. 14, Part $^{2} / 4$.

Rezultati PIAAC na celotnem vzorcu anketiranih v izbranih državah kažejo, da v večini držav odrasli z nižjimi ravnmi spretnosti in nižjo stopnjo dosežene izobrazbe v manjši meri menijo, da lahko vplivajo na politične procese oz. na delovanje vlade v primerjavi z odraslimi, ki dosegajo višjo raven spretnosti in imajo višjo ali visoko stopnjo dosežene izobrazbe (Tabela 6). Povezanost med spretnostmi, izobrazbo in odnosom do političnih procesov je močnejša v Nemčiji in Estoniji, najšibkejša pa v Španiji in na Irskem.

Aktivno državljanstvo starejših ima lahko pozitivne učinke na njihovo vključenost in blaginjo ter prispeva k splošnemu sprejetju vizije aktivnega staranja. Raziskave o politični participaciji starejših kažejo na pozitivno povezavo med izobrazbo in političnim delovanjem (Nygård in Jakobsson, 2013; Melo in Stockemer, 2014). Politična participacija je povezana $\mathrm{z}$ višjim socialno-ekonomskim položajem starejših, predvsem pa so bolj politično angažirani hkrati tudi bolj izobraženi, saj si med izobraževanjem pridobijo spretnosti za razumevanje kompleksnih političnih in ekonomskih vprašanj. Primerjava političnega delovanja med starejšimi in mlajšimi generacijami pokaže, da se starejši politično udej- 
stvujejo na bolj konvencionalen način, tj., da se redno udeležujejo volitev, medtem ko so mlajše generacije vključene $\mathrm{v}$ družbena gibanja, se bolj pogosto udeležujejo protestov in podpisujejo peticije (Melo in Stockemer, 2014, str. 49). V skandinavskih državah starejši udeležbo na volitvah na splošno razumejo kot dolžnost. V tem smislu so aktivni državljani in sestavljajo močno kategorijo volivcev. To dejstvo pa bo s staranjem prebivalstva imelo vse večji vpliv na medgeneracijsko razmerje moči. Raziskava je pokazala, da je mobilizacijski dejavnik politične participacije starejših Skandinavcev poleg socialnih mrež predvsem višja oz. visoka stopnja izobrazbe (Nygård in Jakobsson, 2013, str. 91).

Tabela 7: Starejši (55-65 let) po stopnii izobrazbe in odnosu do vladnih odločitev

\begin{tabular}{|c|c|c|c|c|c|c|}
\hline $\begin{array}{l}\text { IZBRANE } \\
\text { DRŽAVE }\end{array}$ & \multicolumn{2}{|c|}{$\begin{array}{l}\text { Manj kot srednješolska } \\
\text { izobrazba } \\
\text { Zelo se strinjam } \\
\text { Strinjam se - da nimam } \\
\text { vpliva na početje vlade }\end{array}$} & \multicolumn{2}{|c|}{$\begin{array}{l}\text { Srednješolska izobrazba } \\
\text { Zelo se strinjam } \\
\text { Strinjam se - da nimam } \\
\text { vpliva na početje vlade }\end{array}$} & \multicolumn{2}{|c|}{$\begin{array}{l}\text { Višja/visokošolska } \\
\text { izobrazba } \\
\text { Zelo se strinjam } \\
\text { Strinjam se - da nimam } \\
\text { vpliva na početje vlade }\end{array}$} \\
\hline Belgija & 224 & 65,35 & 248 & 61,77 & 113 & 39,00 \\
\hline Češka & 89 & 77,10 & 691 & 67,75 & 188 & 50,97 \\
\hline Estonija & 173 & 74,18 & 540 & 71,85 & 469 & 64,71 \\
\hline Finska & 178 & 50,71 & 182 & 38,01 & 156 & 27,07 \\
\hline Francija & 483 & 74,20 & 471 & 74,28 & 209 & 64,17 \\
\hline Irska & 346 & 73,50 & 113 & 62,32 & 220 & 50,81 \\
\hline Italija & 443 & 81,68 & 224 & 65,46 & 96 & 64,33 \\
\hline Norveška & 84 & 63,99 & 146 & 49,20 & 129 & 27,19 \\
\hline Poljska & 122 & 62,78 & 389 & 48,07 & 102 & 46,28 \\
\hline Španija & 442 & 63,14 & 90 & 59,80 & 112 & 57,42 \\
\hline Švedska & 93 & 50,51 & 169 & 40,53 & 136 & 33,18 \\
\hline $\begin{array}{l}\text { Združeno } \\
\text { kraljestvo }\end{array}$ & 375 & 65,10 & 378 & 54,49 & 255 & 40,07 \\
\hline
\end{tabular}

Vir: mednarodna baza PIAAC (Survey of Adults Skills, 2012).

Naša hipoteza o tem, da se starejši, ki imajo nižjo stopnjo izobrazbe, bolj pogosto strinjajo s trditvijo, da nimajo nobene besede pri tem, kar počne vlada, kot starejši z višjo stopnjo izobrazbe, se je s križanjem podatkov potrdila (Tabela 7). Dvom o moči lastnega vpliva na politične odločitve premosorazmerno upada $\mathrm{z}$ višjo stopnjo izobrazbe $\mathrm{v}$ vseh opazovanih državah. Zaupanje ljudi v politiko je odvisno od življenjskih razmer, ki jih v veliki meri določajo politične odločitve. Eden od kazalnikov zaupanja v politiko je zaznavanje korupcije v posamezni državi. Med izbranimi državami naše analize je največ starejših, ki menijo, da nimajo vpliva na početje vlade, v Italiji, Estoniji, Franciji in delno tudi na 
Češkem. Če te podatke povežemo z raziskavo Eurobarometra o korupciji v državnih institucijah, lahko ugotovimo, da ljudje v vseh omenjenih državah menijo, da je v njihovih državnih institucijah korupcija močno prisotna - nad povprečjem EU-27 (European Commission, 2012, str. 18). Nasprotni trend je v nordijskih državah, kjer je po mnenju anketiranih primerjalno najmanj korupcije $\mathrm{v}$ državnih institucijah. Tudi v naši analizi ponovno izstopajo vse tri nordijske države, saj je med vsemi tremi izobrazbenimi ravnmi najmanj strinjanja s trditvijo o nemoči vplivanja na politiko vlade.

\section{Zdravje}

Četrta dimenzija blaginje v raziskavi PIAAC se proučuje na podlagi samoocene zdravja. Vpliv spretnosti in izobrazbe na zdravje je potencialno obsežen. Ljudje potrebujejo spretnosti procesiranja informacij, da bi lahko razumeli in obvladovali moderne zdravstvene sisteme, ki postajajo vse bolj kompleksni (OECD, 2013, str. 241). T. i. koncept zdravstvene pismenosti povezuje zdravstveno stanje posameznika $\mathrm{z}$ razumevanjem in procesiranjem informacij, povezanih z zdravjem, in sicer od osnovnih informacij o primernem odmerjanju, ki so navedene na škatlici z zdravili, do vsebin gradiv, ki so del javnih zdravstvenih kampanj.

Tabela 8: Dobro, zelo dobro in odlično zdravje

\begin{tabular}{|l|l|l|l|l|l|l|}
\hline $\begin{array}{l}\text { IZBRANE } \\
\text { DRŽAVE }\end{array}$ & $\begin{array}{l}\text { Raven 2 } \\
\text { ali manj; } \\
\text { manj kot } \\
\text { srednja } \\
\text { šola }\end{array}$ & $\begin{array}{l}\text { Raven 2 } \\
\text { ali manj; } \\
\text { srednja } \\
\text { šola }\end{array}$ & $\begin{array}{l}\text { Raven 2 } \\
\text { ali manj; } \\
\text { višja/visoka } \\
\text { šola }\end{array}$ & $\begin{array}{l}\text { Raven 3 } \\
\text { ali več; } \\
\text { manj kot } \\
\text { srednja } \\
\text { sola }\end{array}$ & $\begin{array}{l}\text { Raven 3 } \\
\text { ali več; } \\
\text { srednja } \\
\text { šola }\end{array}$ & $\begin{array}{l}\text { Raven 3 } \\
\text { ali več; } \\
\text { višja/visoka } \\
\text { sola }\end{array}$ \\
\hline Belgija & 0,5372 & 0,6299 & 0,7056 & 0,5900 & 0,7109 & 0,7916 \\
\hline Češka & 0,4611 & 0,7011 & 0,8380 & 0,5241 & 0,7106 & 0,8944 \\
\hline Estonija & 0,5266 & 0,6600 & 0,8112 & 0,6058 & 0,7427 & 0,8477 \\
\hline Finska & 0,4347 & 0,4835 & 0,6587 & 0,4674 & 0,5622 & 0,7478 \\
\hline Irska & 0,5281 & 0,6866 & 0,7657 & 0,6901 & 0,7164 & 0,8246 \\
\hline Italija & 0,6328 & 0,7459 & 0,8240 & 0,6436 & 0,7690 & 0,7818 \\
\hline Norveška & 0,5542 & 0,6790 & 0,8123 & 0,6218 & 0,7352 & 0,8309 \\
\hline Polijka & 0,5353 & 0,7097 & 0,8664 & 0,6764 & 0,7692 & 0,8830 \\
\hline Španija & 0,5654 & 0,6532 & 0,7252 & 0,7062 & 0,7275 & 0,7753 \\
\hline Švedska & 0,6015 & 0,7244 & 0,8006 & 0,6492 & 0,8045 & 0,8776 \\
\hline Z. kraljijtvo & 0,4998 & 0,6667 & 0,6859 & 0,6490 & 0,7370 & 0,7920 \\
\hline
\end{tabular}

Vir: podatki za izbrane države so povzeti iz »OECD Skills Outlook 2013« (OECD, 2013, str. 405), Table A6.14, Part $\frac{4}{4}$.

V vseh izbranih državah odrasli, ki dosegajo nizke ravni spretnosti in imajo končano nižjo stopnjo izobrazbe, na splošno svoje zdravje ocenjujejo manj pozitivno kot tisti, ki dosegajo višje ravni spretnosti in imajo visoko stopnjo izobrazbe (Tabela 8). 
Zdravje je pri starejših izredno pomemben dejavnik, ki določa njihovo dojemanje lastnih zmožnosti in zato tudi njihovo nadaljnjo dejavnost. Nekatere raziskave, ki so bile narejene $\mathrm{z}$ namenom ugotoviti povezanost zdravja $\mathrm{z}$ učenjem in izobraževanjem starejših, razkrivajo, da sta področji tesno obojestransko povezani. Če vzamemo kot izhodišče stopnjo izobrazbe, vidimo, da vsako nadaljnje leto izobraževanja prispeva k zvišanju dohodka in socialno-ekonomskega položaja posameznika; hkrati se bolj izobraženi posamezniki gibljejo po stratifikacijski lestvici navzgor in to posredno vpliva na njihovo zdravje (Hammond, 2004, str. 37-39). Bolj izobraženi starejši so bolj emocionalno prožni, kar pripomore $\mathrm{k}$ boljšemu mentalnemu in fizičnemu zdravju, lažjemu izogibanju depresijam, boljši samopodobi, neodvisnosti, samozavesti in k izstopu iz začaranega kroga nemoči.

Zdravo staranje ne pomeni le podaljšanega življenja, ampak tudi staranje pri dobrem zdravju, in to čim dalj je možno. Številne bolezni v kasnejšem življenjskem obdobju je mogoče preprečiti, na kar opozarjajo mnoge raziskave, ki kažejo na pomembno povezanost med izobrazbo in zdravjem (EAEA, 2012). Tako lahko mentalno stimulativne dejavnosti delujejo preventivno ali zadržujejo napredovanje bolezni, kot sta demenca in Alzheimerjeva bolezen.

Rezultati finske raziskave kažejo, da je pozitivna samoocena zdravja starejših povezana $\mathrm{z}$ njihovo družbeno participacijo, prostovoljstvom in zaupanjem $\mathrm{v}$ druge (Nummela, Sulander, Rahkonen, Karisto in Uutela, 2008). Raziskava o zdravju, staranju in upokojevanju v Evropi (SHARE), v katero je bilo iz 12 držav vključenih 30.023 ljudi, starih 50 let in več, je potrdila pozitivno povezavo med prostovoljstvom in zdravjem, izobrazbo, zadovoljstvom z življenjem in negativno povezavo z depresijo (Haski-Leventhal, 2009). Zanimive so ugotovitve raziskovalcev, da ima izobrazba, pridobljena v mladosti, večji vpliv na zdravje $\mathrm{v}$ starosti kot učne aktivnosti starejših. Razlike $\mathrm{v}$ zdravju med posamezniki z visokimi in nizkimi stopnjami izobrazbe se večajo pri določenih kazalnikih, kot so omejitve mobilnosti, depresivni simptomi, računske spretnosti in časovna orientacija (Kolland in Wanka, 2013, str. 395). V naši analizi smo s križanjem podatkov o stopnji dosežene izobrazbe in samooceni zdravja preverjali hipotezo, da starejši, ki imajo višjo stopnjo izobrazbe, svoje zdravje bolj pogosto ocenjujejo kot odlično, zelo dobro ali dobro v primerjavi s starejšimi, ki imajo nižjo stopnjo izobrazbe. 
Tabela 9: Starejši (55-65 let) po stopnji izobrazbe in samooceni zdravja

\begin{tabular}{|c|c|c|c|c|c|c|}
\hline $\begin{array}{l}\text { IZBRANE } \\
\text { DRŽAVE }\end{array}$ & \multicolumn{2}{|c|}{$\begin{array}{l}\text { Manj kot srednješolska } \\
\text { izobrazba } \\
\text { Ocena zdravja: } \\
\text { odlično, zelo dobro in } \\
\text { dobro }\end{array}$} & \multicolumn{2}{|c|}{$\begin{array}{l}\text { Srednješolska } \\
\text { izobrazba } \\
\text { Ocena zdravja: } \\
\text { odlično, zelo dobro in } \\
\text { dobro }\end{array}$} & $\begin{array}{l}\text { Višja/ } \\
\text { brazbo } \\
\text { Oceno } \\
\text { odličn } \\
\text { dobro } \\
\text { Število }\end{array}$ & $\begin{array}{l}\text { olska izo- } \\
\text { a: } \\
\text { dobro in } \\
\%\end{array}$ \\
\hline Belgija & 242 & 72,29 & 317 & 79,76 & 246 & 85,25 \\
\hline Češka & 68 & 59,44 & 751 & 73,71 & 272 & 86,79 \\
\hline Estonija & 38 & 16,88 & 208 & 27,77 & 328 & 45,25 \\
\hline Finska & 190 & 53,51 & 286 & 58,37 & 449 & 77,09 \\
\hline Francija & 412 & 58,98 & 441 & 67,17 & 263 & 79,76 \\
\hline Irska & 320 & 71,09 & 150 & 80,25 & 383 & 84,01 \\
\hline Italija & 282 & 55,58 & 246 & 69,06 & 121 & 80,90 \\
\hline Norveška & 66 & 48,48 & 210 & 68,88 & 391 & 79,66 \\
\hline Poliska & 71 & 37,34 & 338 & 51,93 & 157 & 70,86 \\
\hline Španija & 350 & 49,29 & 99 & 61,74 & 123 & 71,95 \\
\hline Švedska & 120 & 61,69 & 308 & 73,05 & 364 & 86,45 \\
\hline $\begin{array}{l}\text { Združeno } \\
\text { kraljestvo }\end{array}$ & 193 & 59,89 & 493 & 76,52 & 535 & 84,76 \\
\hline
\end{tabular}

Vir: mednarodna baza PIAAC (Survey of Adults Skills, 2012).

Križanje podatkov potrjuje našo hipotezo, saj v vseh izbranih državah starejši z višjo stopnjo izobrazbe svoje zdravje ocenjujejo bolj pozitivno kot tisti z nižjo stopnjo izobrazbe (Tabela 9). Toda hkrati so med državami opazne razlike. Izstopa zlasti Estonija, kjer so v primerjavi z drugimi državami najmanjši deleži starejših, in to v vseh treh izobrazbenih stopnjah, ki svoje zdravje ocenjujejo pozitivno. Morda lahko te ugotovitve razložimo s pomočjo podatkov o izdatkih, ki jih posamezne države namenjajo za zdravje na prebivalca. V poročilu OECD (2014) »Health at a Glance: Europe 2014 « so namreč med izbranimi državami ti javni izdatki na prebivalca najmanjši ravno v Estoniji, in sicer znašajo 1.086 evrov, povprečje EU-28 je 2.193 evrov, največ javnega denarja za zdravje na prebivalca pa namenja Norveška (4.610 evrov). Slovenija se z 2.003 evri uvršča pod povprečje EU28. Naše ugotovitve bi lahko interpretirali tudi s pomočjo drugih dejavnikov. Tako je na primer finska študija (Nummela idr., 2008) pokazala, da je samoocena starejših ljudi povezana tudi z njihovo socialno participacijo, socialnim kapitalom in zaupanjem. 


\section{SKLEPNE UGOTOVITVE}

Izobraževanje je pomemben dejavnik zmanjševanja družbene izključenosti starejših ljudi in njihovega kakovostnega staranja (Withnall, 2010, str. 14). Pogosto se v zvezi z izobraževanjem in učenjem omenjajo ohranjanje neodvisnosti starejših, spodbujanje zdravega načina življenja, družbena vključenost in dejavnost v civilni družbi, razumevanje in spoštovanje raznolikosti ter spodbujanje izbire in osebnostne rasti v poznejših letih. Čeprav ima izobraževanje starejših veliko terapevtsko vlogo (v smislu spodbujanja mentalne in fizične dejavnosti starejših), je izredno pomembna tudi njegova emancipacijska funkcija, saj starejše spodbuja h kritični presoji lastnega položaja ter k ohranjanju nadzora nad lastnim življenjem in možnostmi (Formosa, 2011, str. 319). Starost vpliva na udeležbo odraslih v izobraževanju, vendar so razlike znotraj posameznih starostnih skupin mnogo večje kot razlike med starostnimi skupinami. Starejši, ki so bili v celotnem življenjskem ciklu učno dejavni, bodo sorazmerno dejavni tudi v pozni starosti, spremenijo pa se namen, cilj in intenzivnost njihove dejavnosti.

Analiza rezultatov PIAAC v izbranih državah na vzorcu starejših kaže, da spretnosti in stopnja izobrazbe starejših pomembno vplivajo na individualno in družbeno blaginjo. Pri tem je med drugim pomembno poudariti, da se po upokojitvi izobražujejo in učijo tisti starejši, ki so se na organiziran način učili tudi v obdobju svojega delovnega življenja (EAEA, 2012). V tem smislu se učenje v kasnejših letih kaže kot nepretrgan proces. Če so ljudje udeleženi v izobraževanju in usposabljanju pri svojih 40. in 50. letih, potem se bodo izobraževali in učili tudi še v kasnejših letih. Rezultati raziskave PIAAC kažejo širše koristi izobraževanja in učenja tako starejših delavcev kot tistih, ki so že upokojeni. Državne politike aktivnega staranja bi zato morale nameniti ustrezno pozornost izobraževanju in učenju starejših prebivalcev, pri tem pa upoštevati njihove potrebe in interese. Razvijati bi bilo treba vsebinsko bolj raznolike in dostopne možnosti izobraževanja starejših, ki bodo ustrezale različnim potrebam heterogene populacije starejših in njenim različnim ciljem; v ta proces pa je nujno vključiti starejše ljudi, ki najbolj poznajo svoje potrebe. Vlade naj bi zagotovile ustrezno financiranje in strukturno podporo za širjenje udeležbe starejših ljudi v izobraževanju in učenju, še zlasti za tiste s slabšim socialno-ekonomskim položajem in nižjo stopnjo izobrazbe. Pri zagotavljanju raznolike in pestre ponudbe izobraževanja in učenja starejših bi vlade morale bolj intenzivno sodelovati s socialnimi partnerji in civilno družbo ter krepiti sodelovanje in vzpostavljanje mrež različnih ponudnikov. Starejšim ljudem je treba ponuditi jasne, natančne in razumljive informacije ter strokovno svetovanje o možnostih njihovega učenja in izobraževanja. Glede na velik pomen prostovoljskega dela starejših in medgeneracijskega učenja pri krepitvi socialne kohezije je treba zagotoviti ustrezno financiranje in zakonske okvire teh dejavnosti. Mentorji, izobraževalci in drugi strokovnjaki, ki delajo s starejšimi ljudmi, potrebujejo dodatno znanje s področja izobraževalne gerontologije, skupnostnega izobraževanja in medgeneracijskega učenja. Šele tako organizirano izobraževanje starejših bi lahko bilo vpliven dejavnik vzpostavljanja blaginje posameznikov, skupnosti in države. 


\section{LITERATURA}

Allman, P. (1984). Self-help Learning and Its Relevance for Learning and Development in Later Life. V E. Midwinter (ur.), Mutual Aid Universities (str. 72-90). Beckenham: Croom Helm.

Anderson, N. D. et al. (2014). The benefits associated with volunteering among seniors: a critical review and recommendations for future research. Psychological Bulletin, 140 (6), 1505-1533.

Battersby, D. (1987). From Andragogy to Gerogogy. Journal of Educational Gerontology, 1, 4-10.

Bjorklund, B. in Bee, H. (2008). The Journey of Adulthood. Upper Sadle River: Pearson Prentice Hall.

Cappeliez, P., Beaupre, M. in Robitaille, A. (2008). Characteristics and Impact of Life Turning Points for Older Adults. Ageing International, 32, 54-64.

EAEA (2012). Older Learners and Intergenerational Solidarity. Conference Report. Pridobljeno s http://www.eaea.org/media/eaea/evants/eaeaconferences/2012/2012_conference_report_active_ageing.pdf.

European Commission (2000). A memorandum on lifelong learning. Brussels: European Commission.

European Commission (2001). Making a European area of lifelong learning a reality. Brussels: European Commission.

European Commission (2006). Adult learning: It is never too late to learn. Brussels: European Commission.

European Commission (2007). Action plan of adult learning: It is always a good time to learn. Brussels: European Commission.

European Commission (2012). Corruption. Report. Special Eurobarometer 374. Pridobljeno s http:// ec.europa.eu/public_opinion/index_en.htm.

Feinstein, L., Budge, D., Vorhaus, J. in Duckworth, K. (2008). The social and personal benefits of learning: A summary of key research findings. London: Institute of Education, University of London.

Field, J. (2005). Social Capital and Lifelong Learning. Bristol: The Policy Press.

Findsen, B. (2005). Learning Later. Malabar: Krieger Publishing Company.

Findsen, B. in Formosa, M. (2011). Lifelong learning in later life. A handbook on older adult learning. Rotterdam, Boston, Taipei: Sense Publishers.

Formosa, M. (2002). Critical Gerogogy: developing practical possibilities for critical educational gerontology. Education and Ageing, 1, 73-85.

Formosa, M. (2011). Critical educational gerontology: a third statement of first principles. International Journal of Education and Ageing, 2(1), 317-332.

Gabrijelčič Blenkuš, M. in Scagnetti, N. (2014). Predupokojitvene priprave za zdravo in aktivno starost. Ljubljana: Nacionalni inštitut za javno zdravje.

Glendenning, F. (1992). Educational Gerontology and Gerogogy: a critical perspective. V C. Berdes, A. A. Zych in G. D. Dawson (ur.), Geragogics: European Research in Gerontological Education and Educational Gerontology (str. 5-22). New York: Haworth Press.

Glendenning, F. (2000). Teaching and Learning in Later Life: theoretical implications. Aldershot: Ashgate.

Hammond, C. (2004). The impact of learning on well-being, menthal health and effective coping. V T. Schuller, J. Preston, C. Hammond, A. Brassett-Grundy in J. Bynner, The Benefits of Learning. The impact of education on health, family life and social capital (str. 37-56). London and New York: RoutledgeFalmer.

Haski-Leventhal, D. (2009). Elderly Volunteering and Well-Being: A Crosws-European Comparison Based on SHARE Data. Voluntas, 20(4), 388-404.

Illeris, K. (2004). The Three Dimensions of Learning. Frederiksberg: Roskilde University Press. 
Jarvis, P. (2001). Learning in later life: an introduction for educators \& carers. London: Kogan Page.

Kahana, E., Bhatta, T., Lovegreen, L. D., Kahana, B. in Midlarsky, E. (2013). Altruism, helping, and volunteering pathways to well-being in later life. Journal of Ageing and Health, 25(1), 159-187.

Klercq, J. (2004). Learning in later life in Europe. Baarn: Odyssee.

Kolland, F. in Wanka, A. (2013). Learning in Later Life. V J. Field, R. J. Burke in C. L. Cooper (ur.), Ageing, Work and Society (str. 380-400). Los Angeles, London, New Delhi, Singapore, Washington: SAGE.

Manheimer, R. J., Snodgrass, D. D. in Moskow-McKenzie, D. (1995). Older Adult Education; A Guide to Research, Programs, and Policies. Asheville: North Carolina Center for Creative Retirement, University of North Carolina.

Melo, D. F. in Stockemer, D. (2014). Age and political participation in Germany, France and the UK: A comparative analysis. Comparative European Politics, 12(1), 33-53.

Motschilnig, R. (2014). Active citizenship and non-worked related aspects of PIAAC. Lifelong Learning in Europe, 1. Pridobljeno s http://www.lline.fi/en/article/advocacy/812014/active-citizenship-and-non-work-related-aspects-of-piaac.

Nummela, O., Sulander, T., Rahkonen, O., Karisto, A. in Uutela, A. (2008). Social participation, trust and self-rated health: A study among ageing people in urban, semi-urban and rural settings. Health \& Place, 14(2), 243-253.

Nygård, M. in Jakobsson, G. (2013). Political participation of older adults in Scandinavia - the civic voluntarism model revisited? A multi-level analysis of three types of political participation. International Journal of Ageing and Later Life, 8(1), 65-96.

OECD (2014). Health at a Glance: Europe 2014. OECD, European Commission. Pridobljeno s http:// www.oecd.org/els/health-systems/health-at-a-glance-europe-23056088.htm.

OECD (2013). OECD Skills Outlook 2013. First Results from the Survey of Adult Skills. Pridobljeno s http://dx.doi.org/10.1787/9789264204256-en.

Pavelek, L. (2012). How can volunteering improve the individual and social life of the elderly. Social and Natural Sciences Journal, 6, 21-24.

Putnam, R. D. (2000). Bowling Alone: The Collapse and Revival of American Community. New York: Simon \& Schuster.

Schuller, T. (2004). Studying benefits. V T. Schuller, J. Preston, C. Hammond, A. Brassett-Grundy, in J. Bynner, The Benefits of Learning. The impact of education on health, family life and social capital (str. 3-11). London, New York: RoutledgeFalmer.

Sivesind, K. H., Posṕišilová, T. in Frič, P. (2013). Does Volunteering Cause Trust? A comparison of the Czech Republic and Norway. European Societies, 15(1), 106-130.

Svet Evropske unije (2011). Resolucija Sveta o prenovljenem evropskem programu za izobraževanje odraslih. Uradni list Evropske unije, C 372/1.

Sztompka, P. (1999). Trust: a Sociological Theory. Cambridge: University Press.

United Nations (1991). Implementation of the International Plan of Action on Ageing and related activities. A/RES/46/91. Pridobljeno s http://www.un.org/documents/ga/res/46/a46r091.htm.

United Nations (2002). Political Declaration and Madrid International Plan of Action on Ageing. Second World Assemly on Ageing. New York: United Nations.

WHO (2002). Active Ageing: a Policy Framework. Geneva: World Health Organization.

Withnall, A. (2006). Exploring influences on later life learning. International Journal of Lifelong Education 1, 29-49.

Withnall, A. (2010). Improving Learning in Later Life. London, New York: Routledge. 